\title{
Production Performance of HyCole, New Zealand White Rabbits and Its Reciprocal
}

\author{
Brahmantiyo B ${ }^{1}$, Raharjo $\mathrm{YC}^{2}$, Prasetyo $\mathrm{LH}^{2}$ \\ ${ }^{1}$ North Maluku Assesment Institute for Agricultural Technology \\ ${ }^{2}$ Indonesian Research Institue of Animal Production \\ E-mail: brahmantiyo@gmail.com
}

(received 12-01-2017; revised 26-03-2017; accepted 27-03-2017)

\begin{abstract}
ABSTRAK
Brahmantiyo B, Raharjo YC, Prasetyo LH. 2017. Performa produksi kelinci HyCole, New Zealand White dan persilangan timbal baliknya. JITV 22(1): 16-23. DOI: http://dx.doi.org/10.14334/jitv.v22i1.1590

Kelinci New Zealand White (NZW) dikenal sebagai kelinci pedaging yang telah beradaptasi baik di Indonesia. Kelinci HyCole merupakan kelinci unggul yang terseleksi reproduksi baik dan laju pertumbuhan tinggi. Peningkatan produktivitas kelinci NZW dapat dilakukan dengan menyilangkan pada kelinci HyCole yang diimpor dari Perancis. Penelitian ini bertujuan untuk mengevaluasi produktivitas HyCole dan New Zealand White serta persilangan timbal baliknya sebagai dasar pembentukan rumpun kelinci pedaging unggul adaptif iklim tropis. Sejumlah 40 induk betina $\left(\mathrm{P}_{\mathrm{B}} \mathrm{P}_{\mathrm{B}}\right)$ dan 17 pejantan $\left(\mathrm{P}_{\mathrm{A}} \mathrm{P}_{\mathrm{A}}\right)$ kelinci $\mathrm{HyCole}$, dan 30 induk betina dan 6 pejantan kelinci New Zealand White (NN). Ransum penelitian diberikan sesuai standar Balai Penelitian Ternak (Balitnak; PK 18 persen, EM 2500 kkal/kg dan SK 14 persen). Ransum berbentuk pellet diberikan pagi dan sore hari, air minum diberikan ad libitum. Pengukuran dilakukan pada kinerja reproduksi induk (litter size lahir, litter size sapih, mortalitas dan bobot badan induk) dan kinerja pertumbuhan anak (bobot badan mingguan dari lepas sapih sampai umur 20 minggu). Data dianalisis dengan menggunakan program SAS (SAS 2001). Data penimbangan ternak kelinci secara periodik dianalisis dengan pendekatan kurva pertumbuhan non linier model Gompertz. Hasil evaluasi menunjukkan bahwa kelinci HyCole yang dikembangkan di Balitnak memiliki performa produksi yang lebih baik dibandingkan kelinci NZW dan persilangan pejantan HyCole dengan NZW betina $\left(\mathrm{P}_{\mathrm{A}} \mathrm{N}\right)$ berpotensi dikembangkan sebagai materi genetik calon induk kelinci unggul adaptif iklim tropis karena memiliki hybrid vigor yang baik pada jumlah anak sekelahiran dan pertumbuhan anaknya.
\end{abstract}

Kata Kunci: Kelinci HyCole, Kelinci New Zealand White, Hasil Persilangan

\section{ABSTRACT}

Brahmantiyo B, Raharjo YC, Prasetyo LH. 2017. Production performance of HyCole, New Zealand White Rabbits and its reciprocal. JITV 22(1): 16-23. DOI: http://dx.doi.org/10.14334/jitv.v22i1.1590

New Zealand White rabbits (NZW) has been known as broiler rabbit that has been well adapted in Indonesia. HyCole rabbits were imported from France that were selected for high reproduction and growth rate. This study was aimed to evaluate the productivity of HyCole and New Zealand White rabbits and their reciprocal as the basis to develop broiler rabbit which adaptive to tropical climate. Forty heads of doe $\left(\mathrm{P}_{\mathrm{B}} \mathrm{P}_{\mathrm{B}}\right)$ and 17 heads of buck $\left(\mathrm{P}_{\mathrm{A}} \mathrm{P}_{\mathrm{A}}\right)$ of HyCole rabbit, and 30 heads of doe and 6 heads of buck of New Zealand White rabbits $(\mathrm{NN})$ were used. The ration was given according to IRIAP standard ration $(18 \% \mathrm{CP}, 2500$ $\mathrm{kcal} \mathrm{ME} / \mathrm{kg}$ and $14 \% \mathrm{CF}$ ). The diet was provided in the morning and the evening, and drinking water was provided ad libitum. Reproductive performance of does (litter size at birth, litter size at wean, mortality and weekly does body weight) and the kit's growth performance (weekly body weight from weaning until the age of 20 weeks) were evaluated. Data were analyzed using the SAS program (SAS 2001). Rabbits growth data were periodically analyzed by Gompertz model (Blasco \& Gomez 1993). HyCole rabbit which was bred in Indonesia had production performance better than NZW rabbit and $\mathrm{P}_{\mathrm{AN}}$ crossbred (HyCole bucks $x$ NZW does) had the potential to be bred as superior rabbit adaptive to tropical climate because they had hybrid vigor of the number of litter size at birth and kit's growth rate.

Key Words: HyCole Rabbit, NZW Rabbit, Crossbred

\section{INTRODUCTION}

Generally, a breeding rabbit proram in the developed countries, follows three-way crossbreeding method, where the first crossing is performed between two selected breeds to produce dam with superior reproduction, is crossed with a sire that has good growth performance (Baselga et al. 2003). It improves the performance of growth and body weight its crossbred. From the economic point of view, daily body weight gain (pre/post-weaning), feed consumption and feed conversion ratio are crucial properties in the livestock productivity.

The Indonesian Resarch Institute for Animal Production (IRIAP) imported 40 heads of dam and 17 heads of sire of HyCole rabbit from France. The rabbit has been well known to have good production and reproduction performances of litter size of more than 9 
kits, and more than $50 \%$ of dam population has 5 pairs of the nipple and the adult weight may reach $2.5 \mathrm{~kg}$ at 10 weeks of age. The observation were on HyCole rabbit parent stock sire A and parent stock dam B (Lenoir et al. 2012). The HyCole rabbit became parental in the crossing with the New Zealand White rabbit.

New Zealand White (NZW) the rabbit has been developed in the United State of America. In 1916, WS Preshaw was the first person who breeds the NZW rabbit to create superior meat producer rabbit. Its origin was unknown, however, it was believed that the Angora rabbit played a role in its forming. Lebas et al. (1986) described that this rabbit was plain white with red eyes and adult weight by $4.1-5.0 \mathrm{~kg}$. The first matting age was 144 days with average litter size by 8.5 kits, life litter size by 8.0 kits and weaned litter size by 6.5 kits. Cheeke et al. (1987) said that the New Zealand White rabbit was known as commercial meat producer. It had fast growth rate, good carcass quality, high fertility and good maternity. Raharjo et al. (1986) described that the NZW rabbit had pregnancy rate by $89.9 \%$, pregnancy time by 31.6 days, calving interval by 37.8 days, dam body weight at the first birth by $3.1 \mathrm{~kg}$, litter size by 9.1 heads, weaned litter size at 5 weeks by 7.2 heads, weaned body weight by $550 \mathrm{~g} /$ head, mortality from the birth to weaned by $16.9 \%$.

The crossing with the CAL was carried out and produced a good result. The crossbred of NZW and CAL had higher growth rate from the weaning to slaughter age compared to its pure breed. Body weight at 70 days of the crossbred of NZW x CAL was higher than the crossbred of CAL $x$ NZW and its CAL pure breed. The body weight of CAL rabbit was the lowest (Maj et al. 2009). The crossbred of NZW x CAL consumed smaller diet per unit body weight gain than the NZW, CAL and the CAL x NZW and reached 2.5 $\mathrm{kg} / \mathrm{head}$ of slaughter weight at the earlier age followed by CAN x NZW, NZW and CAL. The crossing of NZW x CAL has positive effect on growth rate and the slaughter characteristics. Ozimba \& Lukefahr (1991) studied the NZW, CAL and it's reciprocal which showed lower slaughter and carcass weight.

Forming of meat producer rabbit as conducted by 3 crossing of several lines. The dam from crossbred lines was selected for litter size and the terminal sire from a line that was selected for high growth performance (Piles et al. 2000). This study was the beginning of the forming of Superior Rabbit Adaptive to Tropic (KUAT) breed where the HyCole, NZW, and HyLa rabbit were used as the material. Characteristic of hybrid HyCole (sire $\mathrm{P}_{\mathrm{A}} \mathrm{P}_{\mathrm{A}}$ and dam $\mathrm{P}_{\mathrm{B}} \mathrm{P}_{\mathrm{B}}$ became $\mathrm{P}_{\mathrm{A}} \mathrm{P}_{\mathrm{B}}$ ) and its crossing with NZW was required as a standard of determination of prospective KUAT breed forming.
This study was addressed to evaluate the productivity performance of HyCole and New Zealand White and its reciprocal as a basic of breeding activity, the three ways cross informing the superior rabbit adaptive to the tropical climate.

\section{MATERIALS AND METHODS}

This study was conducted at Indonesian Research Institute for Animal Production (IRIAP) for 18 months. This study was used 40 dams $\left(\mathrm{P}_{\mathrm{B}} \mathrm{P}_{\mathrm{B}}\right)$ and 17 sires $\left(\mathrm{P}_{\mathrm{A}} \mathrm{P}_{\mathrm{A}}\right)$ of HyCole rabbit, and 30 dams and 6 sires of New Zealand (NN) rabbit. The matting process resulted in 49 mates of HyCole $\left(\mathrm{P}_{\mathrm{A}} \mathrm{P}_{\mathrm{B}}\right), 29$ mates of New Zealand White (NN), 30 mates of HyCole x New Zealand White $\left(\mathrm{P}_{\mathrm{A}} \mathrm{N}\right)$ and 22 mates of New Zealand White $x$ HyCole $\left(\mathrm{NP}_{\mathrm{B}}\right)$. Those mates resulted in $\mathrm{P}_{\mathrm{A}} \mathrm{P}_{\mathrm{B}}$, $\mathrm{NN}, \mathrm{P}_{\mathrm{A}} \mathrm{N}$ and $\mathrm{NP}_{\mathrm{B}}$ respectively by 389 heads, 185 heads, 212 heads and 181 heads. The matting diagram was presented in Figure 1.

The matting with a ratio of one sire for 4-5 dams was conducted until three parities. The dams were matted after 5-6 months old and 8 months of age. The dams were matted when it showed estrus signs by evaluating the vulva. Redden vulva showed sign of estrus. The palpation was conducted on the $12^{\text {th }}$ day after mating to determine the pregnancy. The dams, which was not pregnant were re-matted. The net for pregnant dams was prepared on the $28^{\text {th }}$ days of pregnancy. The matting was immediately performed on two weeks after giving birth and showed estrus sign. The sire was mated with 4-5 dams. The mating system was adjusted to pedigree note.

The cages were individual wire cage with the size according to the age. The cage height from the floor was $100 \mathrm{~cm}$. Each cage was equipped with diet trough made from pottery by $15 \mathrm{~cm} \times 12 \mathrm{~cm} \mathrm{x} 60 \mathrm{~cm}$ and drinking water was provided in the nipple made from metal. The dam cages size was $60 \mathrm{~cm} \mathrm{x} 75 \mathrm{~cm}$ x $40 \mathrm{~cm}$ while the sire cage size was $75 \mathrm{~cm}$ x $45 \mathrm{~cm} \mathrm{x} 40 \mathrm{~cm}$.

The nesting cage size was $40 \mathrm{~cm} \times 30 \mathrm{~cm} \times 25 \mathrm{~cm}$. The sawdust was used as flooring. The dams would shed their hairs that would be used as a nest for their kits. The nesting cage was cleaned when the kits reached 4-5 weeks old and prepared for the next kits. The kits were weaned at 5 weeks old and maintained in $45 \mathrm{~cm} \times 75 \mathrm{~cm}$ x $45 \mathrm{~cm}$ cage made from wood.

The diet in this study contained crude protein by $18 \%$, metabolic energy by $2500 \mathrm{kcal} / \mathrm{kg}$ and crude fiber by $14 \%$. The diet was made in the form of pellet that was delivered in the morning and the evening while the drinking water was provided ad libitum. 


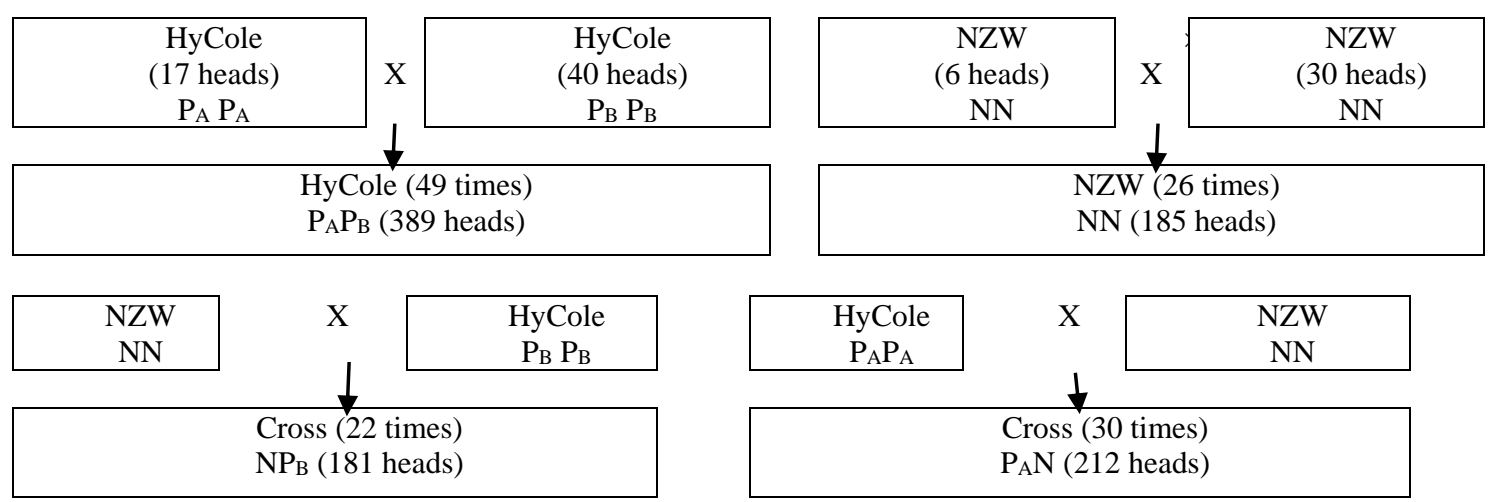

Figure 1. Diagram of mate of the HyCole and New Zealand White Rabbit.

The parameters measured in this study were reproduction performance (birth liter size, weaned litter size, mortality) and dam body weight (from the beginning of giving birth up to next five weeks) and kits growth performance (weekly body weight from after the weaned up to 20 weeks). The whole productivity and reproductivity data were analyzed using SAS program with the general linear model (SAS 2001).

Development of weight data was periodically analyzed using nonlinear growth curve of Gompertz model with SAS package program (SAS 2001). It was considered as a model, based on Blasco \& Gomez (1993), which had been proved as the best model to describe the rabbit growth. The Gompertz was also used in the analysis of the development of mice (Kurnianto et al. (1998), lamb (Lambe et al. 2006) and cattle (Forni et al. 2009).

Kurnianto et al. (1998) said that Gompertz model was a good model in comparing data of body weight with logistic and asymptotic models. For more general utilization, Lenart (2012) reported that Gompertz model was also applied in demography and actuarial. Estimation of maximum-likelihood was used to determine parameters in Gompertz distribution. Goshu \& Koya (2013) stated that Gompertz was one of growth curves that had been used widely along with another growth curves.

The mathematical formula was:

Description:

$$
Y_{t}=A \exp (-B \exp -k t)
$$

$\mathrm{Y}_{\mathrm{t}}=$ body weight at the $\mathrm{t}$ age

$\mathrm{A}=$ adult body size (asymptote) for body weight

$\mathrm{B}=$ scale of variables (constant)

$\exp \quad=$ basic logarithm (2.178282)

$\mathrm{k}=$ growth rate of kits until reached adult body

$\mathrm{t}=$ time unit of age
To obtain estimation value which could be accounted when the biologic point of a growth. P'tak et al. (1994) used a simple model obtained from nonlinear equation derivative. The mathematic model had been used well in estimating the inflection point location when the age and body weight of rabbit experienced the first puberty. To determine the inflection point of body weight, the quotient of $\mathrm{A}$ value and exponential number [A/exp] were used, while the inflection point of age was $[(\operatorname{lnB}) / \mathrm{k}]$.

\section{RESULTS AND DISCUSSION}

\section{Performance of kits}

The growth of kits from the matting of HyCole $\left(\mathrm{P}_{\mathrm{A}} \mathrm{P}_{\mathrm{B}}\right), \mathrm{NZW}(\mathrm{NN})$ and its reciprocal $\left(\mathrm{P}_{\mathrm{A}} \mathrm{N}\right.$ and $\left.\mathrm{NP}_{\mathrm{B}}\right)$ was presented in Table 1 . The $\mathrm{P}_{\mathrm{A}} \mathrm{P}_{\mathrm{B}}$ rabbit had the highest growth rate than the $\mathrm{NN}, \mathrm{P}_{\mathrm{A}} \mathrm{N}$ and $\mathrm{NP}_{\mathrm{B}}$. Birth and weaned body weight ( 6 weeks old) of $\mathrm{P}_{\mathrm{A}} \mathrm{P}_{\mathrm{B}}$ was $54.3 \pm 11.4 \mathrm{~g} / \mathrm{head}$ and $752.7 \pm 161.4 \mathrm{~g} / \mathrm{head}, \mathrm{NN}$ was $53.4 \pm 11.8 \mathrm{~g} / \mathrm{head}$ and $565.9 \pm 121.7 \mathrm{~g} / \mathrm{head}), \mathrm{P}_{\mathrm{A}} \mathrm{N}$ was $56.6 \pm 10.8 \mathrm{~g} / \mathrm{head}$ and $604.4 \pm 200.4 \mathrm{~g} /$ head and $\mathrm{NP}_{\mathrm{B}}$ was $50.4 \pm 8.7 \mathrm{~g} / \mathrm{head}$ and $622.1 \pm 175.8 \mathrm{~g} / \mathrm{head}$. The $\mathrm{P}_{\mathrm{A}} \mathrm{P}_{\mathrm{B}}$ reached slaughter weight $(2.0 \mathrm{~kg} / \mathrm{head})$ at 14 weeks values in the same row with the different suppercript are significant diference $(\mathrm{p}<0.05)$ old by $2,111.9 \pm 462.3 \mathrm{~g} / \mathrm{head}$, while the $\mathrm{P}_{\mathrm{A}} \mathrm{N}$ rabbit was 16 weeks. The $\mathrm{NP}_{\mathrm{B}}$ and $\mathrm{NN}$ rabbit was at 17 weeks old by $2,086.0 \pm 511.9 \mathrm{~g} / \mathrm{head}$ and $2,027.7 \pm 251.3 \mathrm{~g} / \mathrm{head}$ respectively. Maj et al. (2009) reported that crossing of California (CAL) with New Zealand White (NZW) rabbit resulted crossbred that had shorter slaughter age compared its elders by $97 \pm 14$ days of NZW, $105 \pm 17$ of CAL, $96 \pm 13$ days of CAL $x$ NZW and $94 \pm 12$ days of NZW x CAL. 
Table 1. Growth performance of kits of HyCole $\left(\mathrm{P}_{\mathrm{A}} \mathrm{P}_{\mathrm{B}}\right)$, New Zealand White $(\mathrm{NN})$ and its reciprocal $\left(\mathrm{P}_{\mathrm{A}} \mathrm{N}\right.$ and $\left.\mathrm{NP}_{\mathrm{B}}\right)$

\begin{tabular}{|c|c|c|c|c|}
\hline Variables & $\mathrm{P}_{\mathrm{A}} \mathrm{P}_{\mathrm{B}}$ & $\mathrm{P}_{\mathrm{A}} \mathrm{N}$ & $\mathrm{NP}_{\mathrm{B}}$ & NN \\
\hline bb0 & $54.3 \pm 11.4^{\mathrm{b}}$ & $56.6 \pm 10.8^{\mathrm{a}}$ & $50.4 \pm 8.7^{\mathrm{c}}$ & $53.4 \pm 11.8^{\mathrm{b}}$ \\
\hline bb3 & $290.1 \pm 109.7^{\mathrm{a}}$ & $221.2 \pm 66.2^{\mathrm{bc}}$ & $230.1 \pm 59.4^{b}$ & $201.5 \pm 56.2^{\mathrm{c}}$ \\
\hline bb6 & $752.7 \pm 161.4^{\mathrm{a}}$ & $604.4 \pm 200.4^{\mathrm{bc}}$ & $622.1 \pm 175.8^{\mathrm{b}}$ & $565.9 \pm 121.7^{\mathrm{c}}$ \\
\hline bb10 & $1453.9 \pm 324.9^{\mathrm{a}}$ & $1174.82 \pm 324.1^{\mathrm{bc}}$ & $1076.6 \pm 298.9^{b}$ & $985.0 \pm 234.4^{\mathrm{c}}$ \\
\hline bb11 & $1588.4 \pm 371.5^{\mathrm{a}}$ & $1316.20 \pm 338.9^{\mathrm{b}}$ & $1213.0 \pm 301.8^{\mathrm{bc}}$ & $1147.3 \pm 208.6^{c}$ \\
\hline bb12 & $1724.6 \pm 399.2^{\mathrm{a}}$ & $1466.74 \pm 381.0^{\mathrm{b}}$ & $1348.7 \pm 321.6^{\mathrm{bc}}$ & $1297.3 \pm 199.2^{\mathrm{c}}$ \\
\hline bb13 & $1855.3 \pm 402.7^{\mathrm{a}}$ & $1670.34 \pm 435.6^{b}$ & $1473.0 \pm 368.6^{c}$ & $1383.1 \pm 205.1^{\mathrm{c}}$ \\
\hline bb14 & $2111.9 \pm 462.3^{\mathrm{a}}$ & $1819.70 \pm 427.1^{\mathrm{b}}$ & $1573.4 \pm 430.9^{\mathrm{b}}$ & $1465.7 \pm 164.4^{c}$ \\
\hline bb15 & $2288.1 \pm 495.1^{\mathrm{a}}$ & $1955.3 \pm 427.7^{b}$ & $1756.9 \pm 426.8^{\mathrm{bc}}$ & $1687.1 \pm 227.6^{c}$ \\
\hline bb16 & $2394.9 \pm 539.2^{\mathrm{a}}$ & $2075.8 \pm 472.9^{b}$ & $1953.2 \pm 453.1^{\mathrm{b}}$ & $1860.7 \pm 222.8^{b}$ \\
\hline bb20 & $3095.4 \pm 434.0^{\mathrm{a}}$ & $2734.4 \pm 561.6^{\mathrm{b}}$ & $2617.9 \pm 380.8^{\mathrm{bc}}$ & $2483.5 \pm 272.4^{\mathrm{c}}$ \\
\hline
\end{tabular}

Description: bb0-bb20: body weight of $0-20$ weeks old kits

Values in the sama row with the different superscript are significantly difference $(\mathrm{P}<0.05)$

The difference of growth rate was influenced by environment, such as temperature, diet, maintains management (Rao et al. 1978; Gupta et al. 1992), genetic of growth performance of each breed (Sartika \& Diwyanto 1986; Gupta et al. 1992; Lakabi et al. 2004) and interaction between the genetic and environment (Sartika \& Diwyanto 1986). The HyCole rabbit was a selected rabbit for high growth performance of male line and high reproduction of female line which were resulted in hybrid rabbit (final stock) that had combined properties of its pure breeds. The crossing of the CAL and NZW rabbit resulted in better kits growth and carcass performance compared to its elders (Maj et al. 2009; Ozimba \& Lukefahr 1991).

\section{Estimation of growth curve}

The estimation of curve formula of growth of HyCole $\left(\mathrm{P}_{\mathrm{A}} \mathrm{P}_{\mathrm{B}}\right)$, New Zealand White $(\mathrm{NN})$ and its reciprocal $\left(\mathrm{P}_{\mathrm{A}} \mathrm{N}\right.$ and $\left.\mathrm{NP}_{\mathrm{B}}\right)$ using Gompertz model as followed:

$$
\begin{aligned}
& \mathrm{Y}=4,260.61 \exp (-3.88 \exp -0.12 \mathrm{t}) \text { for } \mathrm{P}_{\mathrm{A}} \mathrm{P}_{\mathrm{B}} \ldots \ldots . .(1) \\
& \mathrm{Y}=4,301.85 \exp (-3.71 \exp -0.09 \mathrm{t}) \text { for } \mathrm{NN} \ldots \ldots \ldots . .(2) \\
& \mathrm{Y}=3,827.29 \exp (-3.80 \exp -0.12 \mathrm{t}) \text { for } \mathrm{P}_{\mathrm{A}} \mathrm{N} \ldots \ldots \ldots .(3) \\
& \mathrm{Y}=4,666.30 \exp (-3.61 \exp -0.09 \mathrm{t}) \text { for } \mathrm{NP}_{\mathrm{B}} \ldots \ldots \ldots . .(4)
\end{aligned}
$$

Using those formulations, the graphic of the growth curve for each $\mathrm{P}_{\mathrm{A}} \mathrm{P}_{\mathrm{B}}, \mathrm{P}_{\mathrm{A}} \mathrm{N}, \mathrm{NP}_{\mathrm{B}}$ and $\mathrm{NN}$ may be made. The nonlinear growth curve of Gompertz was presented in Figure 2. It showed that the growth of crossbred was higher compared to the $\mathrm{NN}$ rabbit both the $\mathrm{P}_{\mathrm{A}} \mathrm{N}$ and $\mathrm{NP}_{\mathrm{B}}$
The Gompertz model might have also be used to estimate inflection point of body weight and age of rabbit as showed in Table 2. The inflection point of body weight was a point where the animal experiences a decrease of growth rate at the time unit of the inflection point of age or when the body weight reached its puberty period. Goshu \& Koya (2013) described that the inflection point was a trait of growth curves such as Richard Model, Von Bertalanffy, Brondy, logistic and Gompertz. The inflection point of the growth curve was a point in a curve where the growth rate reaches a maximum value and showing a crucial physical interpretation (Goshu \& Koya 2013).

The inflection point was related to age and body weight. On this point, the auto acceleration step was replaced by autoretardation step (Setiaji et al. 2013). The inflection point of body weight of the HyCole, $\mathrm{NZW}, \mathrm{P}_{\mathrm{A}} \mathrm{N}$ and $\mathrm{NP}_{\mathrm{B}}$ was $1,955.9 \mathrm{~g} / \mathrm{head}, 1,974.9$ $\mathrm{g} /$ head, 1,757.0 $\mathrm{g} / \mathrm{head}$ and $2,142.2 \mathrm{~g} / \mathrm{head}$. This infection point was highly influenced by breed. Brahmantiyo et al. (2010) and Brahmantiyo \& Raharjo (2011) reported that Rex and Satin rabbit reached adult age by 8.6 weeks and 10.3 weeks respectively.

The inflection point in growth curve had high statistical attractiveness (Goshu \& Koya 2013). The HyCole, NZW and its reciprocal were interesting to be observed. The growth rate of kits of the $\mathrm{P}_{\mathrm{A}} \mathrm{N}$ and $\mathrm{NP}_{\mathrm{B}}$ reached inflection point of age which was influenced by both elders. The inflection point of HyCole by 10.6 weeks increased $\mathrm{u}$ to 11.1 weeks after its sire mated with dam NZW $\left(\mathrm{P}_{\mathrm{A}} \mathrm{N}\right)$, while its dam mated with sire NZW $\left(\mathrm{NP}_{\mathrm{B}}\right)$ increased into 14.3 weeks and the NZW itself had age inflection point by 14.6 weeks. 


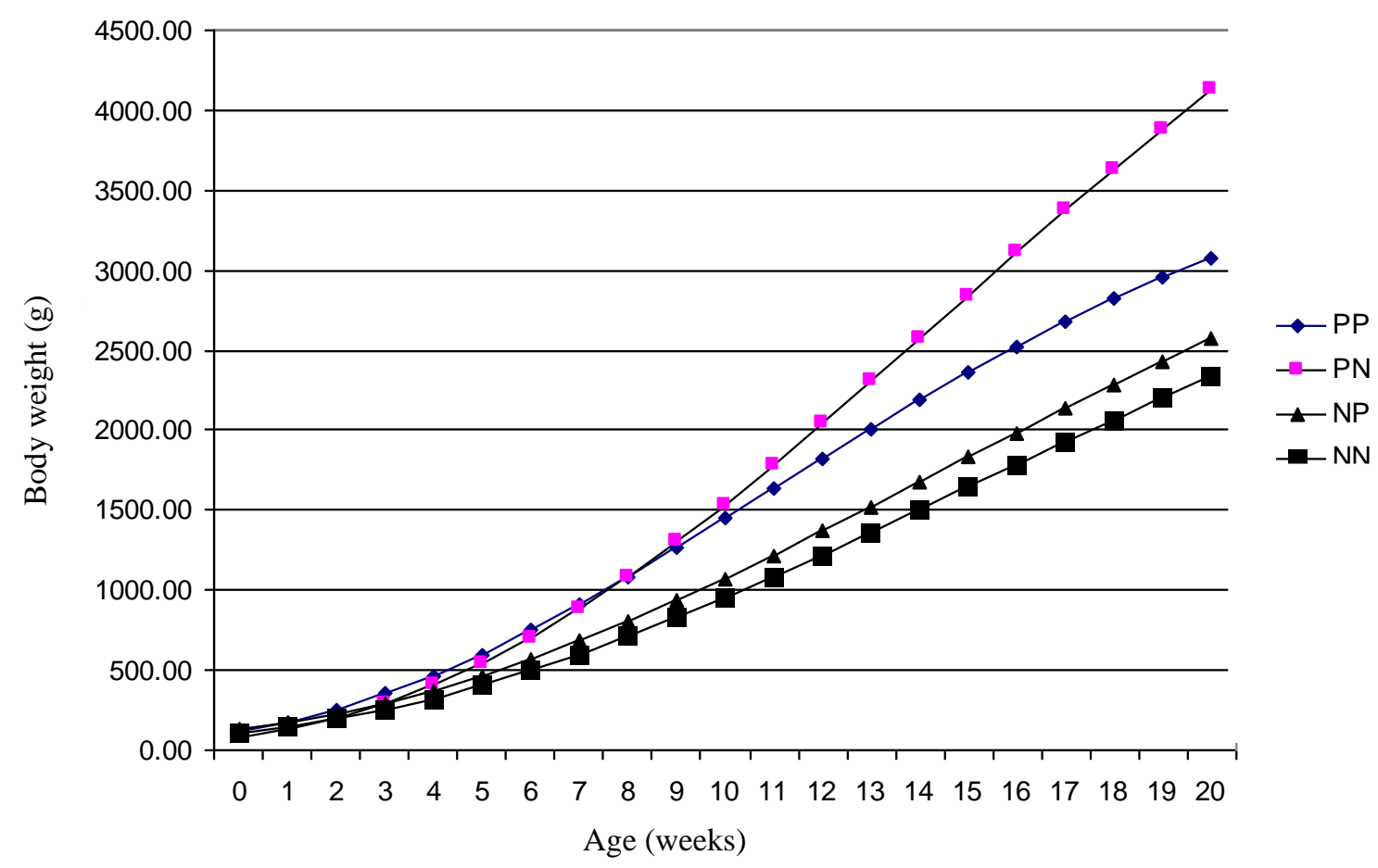

Figure 2. Graphic of growth curve estimation of Gompertz model. $\mathrm{PP}=$ pure HiCole, $\mathrm{NN}=$ pure New Zealand White

Brahmantiyo \& Raharjo (2011) reported that change of growth curve caused by selection of weaning weight of Satin rabbit (SS), increased its puberty weight from $1,301.12 \mathrm{~g}$ to $1,451.05 \mathrm{~g}$ at the same age of 10.3 weeks. While selection of weaning weight of Rex rabbit (RR) and Reza rabbit (RS) increased its puberty weight and time from $1,135.87 \mathrm{~g}$ at 8.6 weeks of age to $1,446.22 \mathrm{~g}$ at 10.1 weeks of age of RR and from $1,080.79 \mathrm{~g}$ on 8.0 weeks of age to $1,571.86 \mathrm{~g}$ on 10.5 weeks of age of RS. Larzul \& de Rochambeau (2004) stated that selection on growth rate would decrease adult age when the animal was slaughtered on the appointed weight (constant), which was reached in the shorter time. They also stated that selection of a growth rate influenced growth path of the rabbit.

According to the estimation of the growth curve of Gompertz model, it might have been estimated that the growth rate was in accordance with the age. The $\mathrm{P}_{\mathrm{A}} \mathrm{P}_{\mathrm{B}}$, $\mathrm{NN}, \mathrm{P}_{\mathrm{A}} \mathrm{N}$ and $\mathrm{NP}_{\mathrm{B}}$ reached puberty age at 10.6 weeks, 14.6 weeks, 11.1 weeks and 14.3 weeks, respectively. The does should be separated to prevent an early mating. Ouyed \& Brun (2008) stated that the formation of broiler rabbit should be following the three ways cross with the dam of crossbred Californian $x$ New Zealand White (CA x NZ) which was mated with the sire Giant Blanc du Bouscat (GB). It then the evaluation result of productivity of the $\mathrm{P}_{\mathrm{A}} \mathrm{P}_{\mathrm{B}}$ and $\mathrm{P}_{\mathrm{A}} \mathrm{N}$ and $\mathrm{NP}_{\mathrm{B}}$ with NN might have been a basis of broiler rabbit formation by adding the $3^{\text {rd }}$ the HyLa breed.

\section{Performance of dams}

The broiler rabbit was widely formed from selected pure rabbit for meat productivity through crossing (Maj et al. 2009). In this study, the evaluation on pure rabbit (HyCole and NZW) and crossing (the reciprocal of HyCole and NZW) were aimed to form broiler rabbit which provided optimal performance. The performance of dams of the HyCole, New Zealand White and its reciprocal was presented in Table 3 . Those dams had no different litter size (birth LS) and the number of weaned kits (weaned LS). The HyCole showed lower reproduction performance compared to the report of Lenoir et al. (2012) who reported that the birth of LS was more than 9 kits. The body weight of HyCole dams had higher birth weight compared to the NZW and its reciprocal at the age of giving birth (BB0) until weaning the kits (BB5).

Mortality of kits of the $\mathrm{P}_{\mathrm{A}} \mathrm{P}_{\mathrm{B}}, \mathrm{P}_{\mathrm{A}} \mathrm{N}, \mathrm{NP}_{\mathrm{B}}$ and $\mathrm{NN}$ was $30.4 \pm 21.1 \%, \quad 34.7 \pm 24.8 \%, \quad 32.9 \pm 22.8 \%$ and $34.6 \pm 21.7 \%$, respectively. This was higher than research result of Sartika \& Diwyanto (1986) which showed average mortality from birth until weaning period at five weeks old was $11.1 \%$ of native rabbit. In Java Island, mortality of kit until weaning age was. 
Brahmantiyo et al. Production performance of HyCole, New Zealand White Rabbits and its reciprocal

Table 2. Estimation of inflection point of body weight and age of $\mathrm{P}_{\mathrm{A}} \mathrm{P}_{\mathrm{B}}, \mathrm{P}_{\mathrm{A}} \mathrm{N}, \mathrm{NP}_{\mathrm{B}}$ and $\mathrm{NN}$

\begin{tabular}{lccc}
\hline Breed & Description & Inflection point of body weight $(\mathrm{g})$ & Inflection point of age (weeks) \\
\hline PAPB & HyCole & 1955.9 & 10.6 \\
PAN & HyCole x NZW & 1757.0 & 11.1 \\
NPB & NZW x HyCole & 2142.2 & 14.3 \\
NN & New Zealand White & 1974.9 & 14.6 \\
\hline
\end{tabular}

Table 3. Production performance of dam of HyCole HyCole $\left(\mathrm{P}_{\mathrm{A}} \mathrm{P}_{\mathrm{B}}\right)$, New Zealand White $(\mathrm{NN})$ and its reciprocal $\left(\mathrm{P}_{\mathrm{A}} \mathrm{N}\right.$ and $\left.\mathrm{NP}_{\mathrm{B}}\right)$

\begin{tabular}{lcccc}
\hline \hline Parameter & $\mathrm{P}_{\mathrm{A}} \mathrm{P}_{\mathrm{B}}$ & $\mathrm{P}_{\mathrm{AN}}$ & $\mathrm{NP}$ & $\mathrm{NN}$ \\
\hline Birth LS & $8.1 \pm 1.9^{\mathrm{a}}$ & $7.2 \pm 1.9^{\mathrm{a}}$ & $8.1 \pm 1.7^{\mathrm{a}}$ & $7.3 \pm 1.9^{\mathrm{a}}$ \\
Weaned LS & $5.8 \pm 1.6^{\mathrm{a}}$ & $4.7 \pm 2.3^{\mathrm{a}}$ & $5.3 \pm 2.1^{\mathrm{a}}$ & $5.5 \pm 2.3^{\mathrm{a}}$ \\
Mortality & $30.4 \pm 21.1^{\mathrm{a}}$ & $34.7 \pm 24.8^{\mathrm{a}}$ & $32.9 \pm 22.8^{\mathrm{a}}$ & $34.6 \pm 21.7^{\mathrm{a}}$ \\
BB0 & $3969.8 \pm 387.6^{\mathrm{a}}$ & $3706.2 \pm 452.8^{\mathrm{b}}$ & $3605.3 \pm 362.4^{\mathrm{bc}}$ & $3478.2^{\mathrm{c}}$ \\
BB1 & $4106.0 \pm 450.6^{\mathrm{a}}$ & $3830.8 \pm 671.7^{\mathrm{ab}}$ & $3746.2 \pm 344.3^{\mathrm{b}}$ & $3545.4 \pm 327.5^{\mathrm{b}}$ \\
BB2 & $3959.3 \pm 367.9^{\mathrm{a}}$ & $3548.7 \pm 462.9^{\mathrm{b}}$ & $3532.3 \pm 393.2^{\mathrm{b}}$ & $3261.9 \pm 471.7^{\mathrm{c}}$ \\
BB3 & $3684.1 \pm 324.3^{\mathrm{a}}$ & $344.3 \pm 514.3^{\mathrm{ab}}$ & $3456.9 \pm 426.5^{\mathrm{ab}}$ & $3290.5 \pm 435.3^{\mathrm{b}}$ \\
BB4 & $3530.4 \pm 431.5^{\mathrm{a}}$ & $3396.4 \pm 478.5^{\mathrm{ab}}$ & $3397.6 \pm 426.5^{\mathrm{ab}}$ & $3136.0 \pm 402.6^{\mathrm{b}}$ \\
BB5 & $3660.9 \pm 331.1^{\mathrm{a}}$ & $3344.7 \pm 373.2^{\mathrm{b}}$ & $3413.8 \pm 514.8^{\mathrm{ab}}$ & $3207.0 \pm 486.9^{\mathrm{b}}$ \\
\hline
\end{tabular}

Description: Different superscript in the same row means significant difference $(\mathrm{P}<0.05)$.

around $14.7-23.3 \%$ (Sastrodihardjo 1985) and the mortality around 20-25\% was fair (Cheeke et al. 1987). Olowofeso et al. (2012) reported that mortality of kits from the crossed rex (RX), Flemish Giant (GF) and Chinchilla $(\mathrm{CH})$ rabbit, reared in the Southwest Nigeria, was $18.26 \%$ (CHxGF) to $30.03 \%$ (GFxRX). While, Raharjo (1994) stated that high mortality (23-43\%) still occured in the breast feeding period. The post-mortem evaluation proved that the highest case of mortality was influenced by enteritis.

The interaction between genetic and environment influenced the mortality of kitHigh mortality in this period was allegedly due to environment effect (climate, wind, and temperature), aeration and hygiene inside the cage and its surrounding which might have caused stress to the kits. Environmental hygiene was a crucial factor influencing the mortality of kits in this study. The death in this study was highly caused by diarrhea and mastitis. Rabbit rearing needed highly hygiene sanitation, smooth airflow and appropriate treatment. Cheeke (1986) described that rabbit development boundary in a tropical region was due to easy experience stress from temperature. Appropriate management was required to monitor the mating, earlier diseases outbreak, patience and attention and much knowledge about the rabbit.
Body weight of dam at the first giving birth of $\mathrm{P}_{\mathrm{A}} \mathrm{P}_{\mathrm{B}}$, $\mathrm{P}_{\mathrm{A}} \mathrm{N}, \quad \mathrm{NP}_{\mathrm{B}}$ and $\mathrm{NN}$ was 3,969.8 $\pm 387.6 \mathrm{~g} / \mathrm{head}$, $3,706.2 \pm 452.8 \mathrm{~g} / \mathrm{head}, 3,605.3 \pm 362.4 \mathrm{~g} / \mathrm{head}$ and $3,478.2 \pm 355.4 \mathrm{~g} /$ head which was influenced by breed. Their body weight was continuous to decrease since the breast feeding entered the fourth week of age. This was due to the dams that had pregnant with new kits. It was required to have known that the dams were re-matted after 14 days of giving birth, so that at the fourth week, the dams had one week pregnant. This required higher nutrient which would be used not only for basic live and kits, but also for the fetus. Sartika \& Diwyanto (1986) said that the dams with high litter size had heavier body weight leading to highest body weight which would e decreasing during the breast feeding period. This study showed that the dams with more kits required better diet quality (Cheeke et al. 1987).

\section{CONCLUSION}

HyCole rabbit hich was developed in Indonesia had better reproduction performance compared to the NZW rabbit. The crossed HyCole sire and NZW dam $\left(\mathrm{P}_{\mathrm{A}} \mathrm{N}\right)$ was potential to be developed as the genetic resources of dam adaptive to tropical climate due to its good heterosity (hybrid vigor) in litter size and its growth. In 
the formation program of Superior Rabbit Adaptive to Tropical (KUAT) with the genetic source of HyCole, Hyla, and NZW rabbit, and performance of the $\mathrm{P}_{\mathrm{A}} \mathrm{N}$ rabbit might have been assigned as dam strain.

\section{ACKNOWLEDGEMENT}

We wish to thank Head of Indonesian Research Institute for Animal Production as a funder and facilitator of this study. Also to Mr. M.I. Shidiqqi who has assisted in exploring the references.

\section{REFERENCES}

Baselga M, Garcia ML, Sanchez JP, Vicente JS, Lavara R. 2003. Analysis of reproductive traits in crosses among maternal lines of rabbits. Anim Res. 52:473-479.

Blasco A, Gomez EA. 1993. A note of growth curves of rabbit lines selected on growth rate or litter size. Anim Prod. 57:332-334.

Brahmantiyo B, Raharjo YC, Martojo H, Mansjoer SS. 2010. Performa produksi kelinci Rex, Satin dan Persilangannya. JITV. 15:131-137.

Brahmantiyo B, Raharjo YC. 2011. Peningkatan produktivitas kelinci Rex, Satin dan persilangannya melalui seleksi. JITV. 16:243-252.

Cheeke PR 1986. Potentials of rabbit production in tropical and subtropical agricultural systems. J Anim Sci. 63:1581-1586.

Cheeke PR, Patton NM, Lukefahr SD, McNitt JI. 1987. Rabbit production. 6th ed. Danville, Illinois (USA): The Interstate Printers \& Publisher Inc.

Forni S, Piles M, Blasco A, Varona L, Oliveira HN, Lobo RB, Albuquerque LG. 2009. Comparison of different nonlinear functions to describe Nelore cattle growth. J Anim Sci. 87:496-506.

Goshu AT, Koya PR. 2013. Derivation of inflection points of nonlinear regression curves-implications to statistics. Am J Theoretical Appl Statistics. 2:268-272.

Gupta SC, Riyazudin, Gupta N, Gurmej Singh. 1992. Growth performance of meat rabbits in semi-arid tropical conditions in India. J Applied Rabbit Res. 15:766-774.

Kurnianto E, Shinjo A, Suga D. 1998. Analysis of growth in intersubspecific crossing of mice using Gompertz model. Asian-Aust J Anim Sci. 11:84-88.

Lakabi D, Zerrouki N, Lebas F, Berchiche M. 2004. Growth performance and slaughter traits of local Kabylian population of rabbits reared in Algeria. Effects of sex and rearing season. [accessed August 20th 2016]. http://dcam.upv.es/8wrc/docs/Meat\%Quality\%20and\%P rocessing/Short\%20Papers/1396-402_lakdjap_mod.pdf.

Lambe NR, Navajas EA, Simm G, Bunger L. 2006. A genetic investigation of various growth models to describe growth of lambs of two contrasting breeds. J Anim Sci. $84: 2642-2654$.

Larzul C. de Rochambeau H. 2004. Comparison of ten rabbit lines of terminal bucks for growth, feed efficiency and carcass traits. Anim Res. 53:535-545.

Lebas F, Coudet P, Rouvier R, de Rochambeau H. 1986. The Rabbit, husbandry, health, and production. FAO. Animal Production and Health Series No.21. Rome (Ital): Food and Agricultural Organization.

Lenart A. 2012. The Gompertz distribution and Maximum Likelihood Estimation of its parameters - a revision. Max Planck Institute for Demographic Research. Germany.

Lenoir G, Garreau H, Banville M. 2012. Estimation of genetic parameters and trends for birth weight criteria in HyCole d line. World Rabbit Science Association. Proceedings 10 th World Rabbit Congress - Sharm ElSheikh - Egypt. p. 183-187.

Maj D, Bieniek J, Łapa P, Sternstein I. 2009. The effect of crossing New Zealand White with Californian rabbits on growth and slaughter traits. Archiv Tierzucht. 52:205-211.

Olowofeso O, Adejuwon AJ, Ademokoya VA, Dorosaro SO. 2012. Breeding and productive performance of three breeds of rabbit in South-West Nigeria. Global J Sci Frontier Res. XII:35-38.

Ouyed A, Brun JM. 2008. Comparison of growth performans and carcass qualities of crossbred rabbits from four sire lines in Quebec. $9^{\text {th }}$ World Rabbit Congress, June 10-13, Verona Italy.p. 189-193

Ozimba CE., Lukefahr SD. 1991. Comparison of rabbit breed types for post weaning litter growth feed efficiency and survival performance traits. J Anim Sci. 69:3494-3500.

Piles M, Blasco A, Pla M. 2000. The effect of selection for growth rate on carcass composition and meat characteristics of rabbits. Meat Sci. 54:347-355.

P'tak E, Bieniek J, Jagusiak W. 1994. Comparison of growth curves of purebred and crossbred rabbits. In: Selection and Quantitative Genetics; Growth; Reproduction; Lactation; Fish; Fibre; Meat. Proceeding of the $5^{\text {th }}$ World Congress on Genetic Applied to Livestock Production. University of Guelph, Canada. p. 201-204.

Raharjo YC. 1994. Potential and Prospect of an integrated Rex rabbit farming in supporting an export oriented agribusiness. LARD Journal. 16:69-80.

Raharjo YC, Cheeke PR, Patton NM. Supriati K. 1986. Evaluation of tropical forages and by product feeds for rabbit production. I. Nutrient digestibility and effect of heat treatment. J Appl Rabbit Res. 9:56-66.

Rao DR, Chen CP, Sunki GR, Johnson WM. 1978. Effect of weaning and slaughter ages on rabbit meat production. II. Carcass quality and composition. J Anim Sci. 46:578.

[SAS] Statistical Analysis System. 2001. SAS/STAT user's guide Release 8.2. Statistical Analysis System. Cary NC (USA): SAS Institute Inc. 
Sartika T, Diwyanto K. 1986. Produktivitas kelinci lokal : Litter size, pertumbuhan, mortalitas dan kondisi induk. Ilmu dan Peternakan. 2:117-122.

Sastrodihardjo. 1985. Performan reproduksi kelinci (Oryctogalus cuniculus) pada peternakan kelinci di Jawa. Prosiding Seminar Peternakan dan Forum
Peternakan Unggas dan Aneka Ternak. Bogor (Indones): Indonesian Center for Animal Research and Development.

Setiaji A, Sutopo, Kurnianto E. 2013. Growth analysis in rabbit using Gompertz non-linear model. J Indonesian Trop Anim Agric. 38: 92-97. 